\title{
Personality Rights - A Universal Tool for the Recovery of Non-Pecuniary Loss
}

\author{
By Martyna Kasperska*
}

\begin{abstract}
As society develops, the concept of personality rights and their legal protection gain significance over the years. Naturally, this concept is evolving as society changes, and it should protect new personal interests against infringement. At the same time, there are reported instances of granting legal protection with doubtful legal justification. In Poland, many commentators and scholars point out that the courts, in some cases, seem to use the concept of personality rights as a universal tool in order to compensate for nearly any mental distress. In this paper, I wish to present interesting examples of this "search" for new personality rights as tools to compensate the plaintiffs for non-pecuniary damages, along with some controversial cases of granting non-pecuniary damages based on questionable legal justification. Following, I will attempt to clarify the notion of non-pecuniary loss and examine whether the courts try to expand its meaning to grant legal protection to plaintiffs. My analysis will be based on Polish law, with some comparative remarks. As the problem is complex and varies according to the jurisdiction, this paper provides a general illustration of the issue at hand.
\end{abstract}

Keywords: Tort law; Personality rights; Non-pecuniary damage; Nonpecuniary loss; Compensation

\section{Introduction}

This paper aims to illustrate the problem of using the concept of personality rights' protection in order to request compensation for non-pecuniary damage. In Poland, scholars and the courts themselves note a considerable growth of cases in which plaintiffs use the concept of personality rights to successfully gain compensation for non-pecuniary loss, based on doubtful legal arguments. As society develops, it not only influences the whole concept of personality rights' protection but also contributes to greater legal awareness among its members. The character of personality rights is vague by nature, and therefore the concept is sometimes used as a tool to justify the protection of interests that, from a legal point of view, should not be protected. The examples presented in this paper provide only a limited illustration of a more general problem. Each of the cases could generate a separate extensive discussion, and this paper does not attempt to offer a complex analysis of the problem but rather bring to the forefront an important phenomenon that deserves widespread attention. Although the problem described in the paper is observed and discussed from the perspective of Polish law, I also include several comparative remarks.

${ }^{*} \mathrm{PhD}$ Candidate, the Doctoral School at the University of Silesia, Faculty of Law and Administration, University of Silesia in Katowice, Poland. Email: martynakasperska@ gmail.com. 
Following, I offer a brief description of the concept of personality rights in Poland and present different problematic aspects of compensating non-pecuniary losses, including compensation for infringement of family bonds, national identity and national dignity and non-pecuniary loss resulting from non-performance or improper performance of a contractual obligation.

\section{Personality rights in Poland}

It is generally accepted that personality rights are private law rights that are non-patrimonial and highly personal by nature, since they are inseparably bound to personality. ${ }^{1}$ The infringement of a personality right primarily results in personality harm, non-pecuniary loss or ideal damage, which is any damage or harm to a personality interest that does not affect a person's patrimony and cannot be easily calculated. ${ }^{2}$ Personality rights can be generally defined as rights relating to legitimate personality interests protected by the law of delict. They can be described as a hybrid between fundamental human rights (in the context of public law) and subjective rights (in the meaning of private law). ${ }^{3}$ The subject of personality rights is not easy to describe and categorise as their various aspects overlap, and while comparing the concept of personality rights in the diverse legal system, one has to consider both systematic and cultural differences. ${ }^{4}$

Before analysing the details of Polish regulations in this matter, it is imperative to understand the common approaches to the concept of personality rights' protection. This concept can be based on a single general personality right approach or several narrower individual personality rights. A third approach involves focusing on the conduct, endangering particular interests rather than the protected interests themselves. ${ }^{5}$ Poland adopted the second approach, providing legal protection to certain individual personality rights. The list of personality rights in the Polish civil code is non-exhaustive, and it is possible to identify other personality rights not specified in the code. ${ }^{6}$ It also must be noted that Polish public law is of great significance when discussing the protection of personal rights in private law. The Polish Constitution has an especially strong influence on the interpretation of personality rights' civil law regulations. ${ }^{7}$ According to Art. 23 of Polish civil code (further referred to as $\mathrm{CC}$ ), ${ }^{8}$ a human being's personality

\footnotetext{
${ }^{1}$ Neethling (2005) at 223.

${ }^{2}$ Ibid, at 224 .

${ }^{3}$ Brüggemeier (2010) at 6.

${ }^{4}$ van $\operatorname{Dam}(2013)$ at 185.

${ }^{5}$ Steininger (2018) at 14. See also Neethling (2005) at 211-218; van Dam (2013) at. 184.

${ }^{6}$ However, under Art. 30 of the Polish Constitution, it is a person's dignity that constitutes the basis for any other personality right protected by law.

${ }^{7}$ Kubiak-Cyrul (2013) at 76: "“...] there is a close relationship between the category of fundamental rights guaranteed in constitutional law and the subjective rights recognized in private law. The content of personal subjective rights is strongly conditioned by the scope of fundamental rights forming a superior category, which must be taken into account in the process of applying the law." ${ }^{8}$ The Act of 23 April 1964 - Civil Code (Journal of Laws of 2020 item 1740 as amended). Translation of the Polish CC provisions into English by Kancelaria "Kuczek-Maruta" - Bil, T.,
} 
rights, such as health, freedom, dignity, freedom of conscience, surname or pseudonym, image, correspondence confidentiality and home inviolability as well as scientific, artistic, inventive and reasoning activities, shall be protected by the civil law regardless of the protection provided for in other provisions. The means for personality rights' protection are provided in the subsequent Article. The last sentence of Art. 24 section 1 of CC provides that a person whose personality rights are threatened by another person's actions may, among others means of protection, demand monetary recompense according to the terms provided for in the civil code. ${ }^{9}$ This Article is complemented by Art. 445 and 448 of Polish CC, which provisions allow the aggrieved party to demand compensation for the harm suffered due to infringement of their personality rights.

The non-exhaustive character of the personality rights' list can result in problems concerning the creation, or rather discovery, of new personality rights. The increase of a demanding attitude in society is particularly visible in the field of personality rights, as in case of an infringement, plaintiffs are not required to prove pecuniary damage. Nowadays, the judicature is more often inclined to recognise new rights relating to personality, loosely related to the constitutionally protected human's dignity, from which they are traditionally derived. ${ }^{10}$ As a result, it is necessary to consider the common features of all personality rights and select those interests that not only are worth protecting but also have a strictly individual character. ${ }^{11}$ Certain mechanisms are needed to select these interests, infringement of which result in liability for damages. ${ }^{12}$

Polish scholars have noted the problems that may derive from the ambiguous nature of personality rights. Under current regulations, it is not possible to compensate non-pecuniary damage if personality rights were not infringed. ${ }^{13}$ However, Polish courts grant protection to individuals who suffered non-pecuniary damage, while simultaneously their personality rights, understood as non-

Broniek, A., Cincio, A. \& Kiełbasa, M. (translation), Dannemann, G. (consultation), Frederick Fischer, S. \& Zoll F. (consultation and review).

${ }^{9}$ The exact wording of Art. 24 of Polish civil code is as follows: $\S 1$. A person whose personal interests are jeopardised by another person's action may demand that the action be abandoned, unless it is not illegal. In the case of actual violation, he may also demand that the person who committed the violation perform acts necessary to remove its consequences, in particular that the latter make a statement of a relevant content and in a relevant form. On the basis of the principles provided for by the Code he may also demand pecuniary compensation or a payment of an adequate amount of money for a specified community purpose; $\S 2$. If, as a result of a of personal interest damage to the property was inflicted, the injured party may demand it to be redressed on the basis of general principles; $\S 3$. The above provisions shall not prejudice the entitlements provided for by other provisions, in particular by copyright law and by patent law.

${ }^{10}$ Strugała (2019) in Chapter V, para. 2.

${ }^{11}$ Grzeszak (2018) at 7, 12.

${ }^{12}$ In tort law generally there are mechanisms that allow for this selection: on the one hand, they can exclude protection of some categories of interests upfront (in abstracto), and on the other hand they can exclude protection of recognised interests under the circumstances of a particular case (in concreto). In Polish law, when it comes to compensation of non-pecuniary loss, the prerequisite of a certain personality rights infringement plays a role of a filter - Strugała (2019) in Chapter III, para.7.

${ }^{13} \mathrm{~A}$ general basis for tortious liability is provided in Art. 415 of Polish CC, which states that a person who caused damage to another person by their own fault shall be obliged to redress it. This provision allows for compensation of pecuniary damages only. 
pecuniary interests strictly related to the individual, were not infringed. ${ }^{14}$ This could lead to a situation when any unpleasantness suffered by people can be translated into money. ${ }^{15}$ The courts often decide to award compensation, using the concept of personality rights' protection, as the award seems just from an axiological point of view, and the legal system lacks adequate tools to grant protection. ${ }^{16}$ Thus, the personality rights' concept is used as a tool of sorts, to complement imperfect or insufficient legislation. This phenomenon may lead to the excessive expansion of the personality rights' concept beyond the borders intended by the legislator.

\section{Compensation for Non-Pecuniary Loss}

Generally, one of the main remedies available to a party whose personality rights were infringed is compensation for pecuniary and non-pecuniary loss. Cases for non-pecuniary loss seem to be more difficult than cases in which pecuniary loss is at stake, as they inevitably lead to the problematic question of whether the infringement resulted in non-pecuniary loss and how to assess non-pecuniary interest in monetary terms. ${ }^{17}$ Non-pecuniary harm should be understood as an actual loss, as it implies a detriment beyond the pure normative detriment resulting from the violation of the legal norm. ${ }^{18}$ For instance, the French legal system is generally open to compensate for the non-pecuniary loss suffered due to violation of a personality interest. At the same time, German courts require the existence of a grave violation of the personality right to justify monetary compensation for nonpecuniary loss. ${ }^{19}$

\section{Protection of Family Bonds}

One of the commonly noted problematic examples of claims for nonpecuniary damages is a claim of a person close to an aggrieved person, even if that person is deceased. It is noted that most European legal systems allow for compensation in the event of the death of the direct victim. ${ }^{20}$ In Poland, since 2008 the closest members of a deceased's family may claim compensation for the harm suffered by the deceased. ${ }^{21}$ Despite this, the problem remains valid, as there is still no consensus on whether compensation can be awarded to family members of a person who has suffered an injury or health disorder. Since the Polish Supreme Court has issued contradictory rulings on this matter, the panel of combined chambers of the Supreme Court (Civil Chamber and Extraordinary Review and

\footnotetext{
${ }^{14}$ Ibid, at 8 .

${ }^{15}$ Ibid, at 25 .

${ }^{16}$ Traple (2020) at 140

${ }^{17}$ Steininger (2018) at 19.

${ }^{18}$ Banakas (2015) at 304.

${ }^{19}$ Steininger (2018) at 20, and the literature referenced there.

${ }^{20}$ Rogers (2005) in Lahe \& Kull (2016) at 2.

${ }^{21}$ Under Art. 446 section 4 of Polish CC: The court may also grant a relevant amount to the closest family members of the deceased on account of pecuniary compensation for the wrong suffered. The provision came into force on August 3, 2008.
} 
Public Affairs Chamber) is about to answer the question of whether a person close to the aggrieved person can claim compensation due to inability to establish or continue a typical family bond. In other words, the Supreme Court will analyse whether a family bond can constitute a personality right, and, consequently, whether the plaintiff can claim compensation for the harm caused by the infringement of a family bond.

Previous judgement of the Supreme Court resulted in diverse conclusions. In the 2008 resolution, the Supreme Court stated that a family bond is one of the legally protected personality rights, even if it exists under different names (e.g. a family bond, a right to family life). ${ }^{22}$ The Court referred to the provisions of the Draft Common Frame of Reference (DCFR, 2009) and the Principles of European Tort Law (PETL, 2005), which adopted the principle of compensation for nonpecuniary damage suffered by the persons close to the aggrieved party. On the other hand, in the 2019 resolution, the Supreme Court stated that there is no such personality right as a right to family bonds. ${ }^{23}$ The Court explained that Art. 446 section 4 of the Polish CC clearly limits the option of claiming compensation and cannot also cover the situation when the aggrieved party is alive. The Court reasonably argued that traditionally in Polish law, there is no general rule that every non-pecuniary damage is subject to compensation. Therefore, there must always be a clear normative basis for awarding compensation for such damage. In other words, the mere fact that a person has suffered harm does not yet prejudge the legitimacy of their claim. Furthermore, the Court stated that it is clear that the harm itself does not prove that a particular personality right has been infringed, as there is a whole spectrum of non-pecuniary interests (both protected and unprotected by law) that do not have the form of rights relating to personality. According to the Court, the mere fact that a specific person has suffered even serious harm is therefore not sufficient for awarding the compensation if there has been no infringement of personality rights or there has been no other particular legal basis for compensation.

The abovementioned problem is not limited to Poland. In Estonia, a similar debate started after the claimant sought compensation for non-pecuniary damage due to the death of both parents in a traffic accident caused by a person without a valid permit to drive. ${ }^{24}$ However, under the Estonian Law of Obligations Act, it is possible to request compensation for such damages if exceptional circumstances justify compensation. ${ }^{25}$ The court dismissed the claim, finding no exceptional circumstances. In a case heard by the Austrian Supreme Court, the Court confirmed the decision of the lower court refusing to grant leave for a claim petitioning for compensation of a non-pecuniary loss suffered by a seven-month-old baby who would grow up without a grandfather killed in a car accident. According to the Court, the minor could not set forth either injury to health or bereavement, and it is

\footnotetext{
${ }^{22}$ The resolution of the Supreme Court dated 27 March 2018 (III CZP 36/17).

${ }^{23}$ The resolution of the Supreme Court dated 22 October 2019 (I NSNZP 2/19).

${ }^{24}$ Lahe \& Kull (2016) at 2.

${ }^{25}$ The Estonian Supreme Court stated that this additional prerequisite will be met in cases such as the spatial (physical) proximity of the claimant to the aggrieved party. Ibid, at 5 .
} 
unclear whether they would suffer compensable mental harm because of having to grow up without their grandfather. ${ }^{26}$

Although in some cases Polish courts recognised the right to family bonds in case of death or injury of a relative, they were hesitant to protect family bonds in cases of family conflicts. In a judgement from December 11, 2018, the Polish Supreme Court excluded the possibility of awarding compensation for nonpecuniary damages caused by an infringement of family ties. The Court argued that in the case of so-called marital infidelity, the provisions on the protection of rights relating to personality do not apply to the protection of family legal ties between spouses. ${ }^{27}$ In this case, the Court abstained from focusing on the harm itself, and instead emphasised the practical consequences of granting a possibility of compensation. As compensation is only one of the remedies available for a party whose personality rights were infringed, other adequate remedies, such as claims of prohibitive character, would have to be accepted. Thus, it would be possible to accept the spouse's claim regarding, for example, prohibiting a specific person from approaching their spouse. The legal obligation of marital fidelity should not be qualified as an obligation to respect a personality right since it exists only in the relationship of the spouses (inter partes). However, the concept of personality rights' protection aims to protect the individual, non-pecuniary interest of the entitled person, which is protected by the law effective erga omnes. ${ }^{28}$

Interestingly, tortious liability for breach of marriage duties was the subject of an Italian case, where the plaintiff, after having divorced her husband, brought an action for damages due to violation of marriage duties that resulted in pecuniary and non-pecuniary losses. The Italian Supreme Court upheld the plaintiff's claim, confirming the trend to extend the tort law protection and compensation for nonpecuniary losses to family relationships. ${ }^{29}$

Another interesting example of claims for non-pecuniary damage are those connected to bonds with animals. Although compensation of non-pecuniary damage resulting from the loss of an animal is rare, in one of the cases, the court found that the bond with an animal could be regarded as a right relating to personality. $^{30}$

\footnotetext{
${ }^{26}$ Judgement of the Austrian Supreme Court (Oberster Gerichtshof - OGH) dated 12 May 2005 (2 Ob 41/03y) cited by Steininger (2005) at 134-135.

${ }^{27}$ Judgement of the Polish Supreme Court dated 11 December 2018 (IV CNP 31/17).

${ }^{28}$ Grzeszak (2019) at 608.

${ }^{29}$ Judgement of the Italian Supreme Court dated 15 July 2005 (no. 15022) cited by Bargelli (2005) at 375-377.

${ }^{30}$ Judgement of the Regional Court in Cracow dated 7 September 2017 (II Ca 1111/17). In another case the Regional Court in Koszalin found that stealing a cat can result in infringement of mental health, being indisputably a personality right (judgement of 22 February 2011, I C 124/10). Although, axiological reasons for these rulings are understandable, the protection granted under personality rights' regulations is questionable. The Court of Appeal in Białystok in the judgement dated 13 January 2021 (I ACa 289/20) decided otherwise. The Court stated that an emotional bond with an animal cannot constitute a personality right and even commonly accepted intangible values do not automatically become subject of to legal protection proper to personality rights.
} 


\section{Protection of National Identity and National Dignity}

A sense of national identity and national dignity are "new" personality rights, whose legitimacy is disputable in the Polish legal discourse. ${ }^{31}$ However, the Polish court's rulings on possible infringement of personality rights caused by the use of terms such as "Polish concentration camps" were equivocal.

In one of the cases, the plaintiff, a former concentration camp prisoner, claimed to have suffered a non-pecuniary loss when a publisher of an internet portal used the term "Polish death camp" in one of its articles. The plaintiff argued that she was particularly close to the history of the Polish nation, particularly regarding the war experiences and the memory of the crimes committed against Polish citizens. She felt outraged that the article published by the defendant associated the Polish nation with the organisation of concentration camps, indicating the infringement of her national identity and national dignity as a basis for her claim. The Court considered that the plaintiff was acting as a representative of the whole nation, and the claim was aimed not at the protection of the plaintiff's own personality rights but rather in defence of specific values and interests of a collective nature. ${ }^{32}$

In a case with similar factual circumstances, the courts of both instances agreed that the defendant, using the phrase "Polish death camps" in a program announcement on its website, infringed the plaintiff's personality rights such as human dignity, national identity and national dignity. The Appellate Court ruled that, contrary to the defendant's arguments, national identity and dignity belong to the list of protected personality rights, and in this case, the requirement of individualisation of the infringement was met. The Appellate Court agreed with the Regional Court's justification that since the plaintiff was a prisoner of the concentration camp mentioned in the defendant's announcement and took an active part in activities to preserve the memory of the concentration camps' tragedy, he proved that his personality rights were infringed. According to the Court, the use of a similar wording does not automatically mean that the personality rights of every member of the Polish nation could be infringed. In the plaintiff's case, as he was a former prisoner of a concentration camp, using the abovementioned term infringed his national identity and national dignity, resulting in a non-pecuniary loss. ${ }^{33}$

Finally, the most interesting ruling was issued by the Appellate Court in Warsaw. The plaintiff was a grandson of a concentration camp prisoner who died

\footnotetext{
${ }^{31}$ The discussion grew even more intense in 2018, after the introduction of an amendment to the Act on the Institute of National Remembrance that provided the option to claim compensation because of damage to the reputation of the Republic of Poland or the Polish nation. The reason for the amendment was the use of terms such as "Polish concentration camps" in the mass media. According to the new law, the State Treasury can claim both pecuniary and non-pecuniary damages in case of infringement. The critics of the amendment indicate that neither the Republic of Poland nor the Polish nation can be subject to personality rights as they are not subject to civil law relations. ${ }^{32}$ Judgement of the Regional Court in Olsztyn dated 24 February 2015 (I C 726/13). The appeal against this judgement was dismissed by the Appellate Court in Bialystok on 30 September 2015 (I ACa 403/15).

${ }^{33}$ Judgement of the Appellate Court in Cracow dated 22 December 2016 (I ACa 1080/16).
} 
in the camp. The plaintiff claimed his national identity and national dignity were infringed because of the defendant's article, in which the term "former Polish concentration camp" was used. The defendant claimed that the phrase was used by mistake and that the proper apology was published. The court of first instance dismissed the claim. The Court stated that even though national identity and national dignity remained under legal protection as rights relating to personality, only a person directly affected by the offensive term could demand protection. Furthermore, the Court found that the defendant's statement referred to a group of unidentified people and not directly to the plaintiff or his family. The court of appeals found differently. The Appellate Court stated that the term used by the defendant referred directly to the plaintiff as it falsified the legacy that had a significant influence on the plaintiff's personality, bearing in mind that the plaintiff's grandfather died in a concentration camp. However, the Appellate Court upheld the judgement, indicating that the defendant, having published an apology, performed the actions necessary to remove the consequences of the infringement. ${ }^{34}$

The critics of the last ruling emphasise that personality rights should be understood as individual ("egoistic") interests and not as general values important to society as a whole. ${ }^{35}$ Individual members of the society do not have an individual interest in seeking protection since the infringement concerns an abstract community. ${ }^{36}$ Otherwise, one can easily imagine a situation where numerous claims could be brought by members of different communities determined to protect commonly recognised general value infringements that do not affect them personally. Legal instruments adequate for civil law relations do not seem to be appropriate for the protection of "common values."

\section{Non-Pecuniary Loss Resulting from Non-Performance or Improper Performance of a Contractual Obligation}

It is commonly accepted that in Polish law awarding compensation for nonpecuniary loss is possible under an unambiguous normative basis. For that reason, the attempts to interpret the current regulations in a way that allows the protection of non-pecuniary interests as part of contractual relations are not convincing. ${ }^{37}$ As the regulation on compensation is included in the part of the Polish Civil Code devoted to tort, it limits the possibility to remedy the harm only to cases in which the infringement of personality rights results from a tort. ${ }^{38}$ However, the Polish courts more and more often award non-pecuniary damages on contractual grounds, using the concept of personality rights' protection in cases when the harm suffered comes down to disappointment or discomfort resulting from the failure to achieve the contract's purpose. ${ }^{39}$

\footnotetext{
${ }^{34}$ Judgement of the Appellate Court in Warsaw dated 31 March 2016 (I ACa 971/15).

${ }^{35}$ Grzeszak (2018) at 23.

${ }^{36}$ Ibid, at 24.

${ }^{37}$ Kryla-Cudna (2018) at Chapter II, para. 3.5.6.

${ }^{38}$ Ibid.

${ }^{39}$ Traple (2020) at 141 . The discussion in this matter was strongly influenced by the judgment of the European Court of Justice (Sixth Chamber) of 12 March 2002 in case C-168/00, Simone Leitner v. TUI Deutschland GmbH \& Co. KG. in which the Court ruled that the Art. 5 of Council Directive
} 
On the other hand, there are strong arguments in favour of changes that will allow the possibility of compensation for non-pecuniary loss under the contractual regime. Comparative legal arguments, as well as global development trends, indicate that the development of European regulations on this matter has left the Polish legal system behind. Social expectations and a growing number of claims in fields such as medical and tourist services speak for the practical significance of the problem. Most European legal systems accept that any personal injury, including harm, should be subject to redress, regardless of the liability regime. ${ }^{40}$ However, not all non-pecuniary interests can and should be classified as personality rights. This possibility is often excluded due to their relative nature or a considerable degree of subjectivity, and thus these interests should not be artificially put into the list of rights relating to personality. ${ }^{41}$ Even if certain interests not included in the personality rights' list deserve legal protection, it is the legislator who should define the protection's legal frames.

\section{Conclusions}

The cases illustrated in the paper give us a certain perspective on a problem related to non-pecuniary loss. The definition of non-pecuniary loss is being extended to all kinds of mental distress, discomfort and dissatisfaction. Under the Polish CC, it is impossible to compensate any non-pecuniary loss based only on general provisions on tortious liability. In order to make such a claim, one must prove that the non-pecuniary loss resulted from the infringement of the personality rights of the aggrieved party. It seems that the concept of personality rights is sometimes used (or even "misused") to cover certain interests that do not conform to the definition of personality rights due to their features. Thus, the concept of personality rights is extended and the courts discover new personality rights to justify protection, which seems desirable from the axiological point of view. The necessity to compensate for the non-pecuniary damage serves as a means by which new personality rights are determined. The courts try to improve the legal system's weaknesses using the instruments readily available. Comparison with other European legal systems leads to the conclusion that even recognition of the possible flaws of current regulations cannot justify using the concept of personality rights as a tool to compensate the non-pecuniary loss in such situations when personality rights are, in fact, not infringed.

90/314/EEC of 13 June 1990, on package travel, package holidays and package tours, is to be interpreted as conferring on consumers, in principle, a right to compensation for non-material damage resulting from the non-performance or improper performance of the services constituting a package holiday.

${ }^{40}$ Bagińska (2021) at 122 and the literature referenced there. The author refers to the amendment to the Dutch and German civil codes in this regard. In 2018, an amendment to the Dutch Civil Code introduced a claim for compensation both in the event of death and serious damage to health or in the event of invalidity and provided for flat-rate compensation. In 2017, an amendment to the German Civil Code provided the possibility to award compensation for relatives in the event of death of the directly injured person - see Bagińska (2021) at 131.

${ }^{41}$ Ibid, at 123 . 


\section{References}

Bagińska, E. (2021). 'O granicach kompensacji szkody niemajątkowej w przyszłym kodeksie cywilnym (uwagi na tle prac Komisji Kodyfikacyjnej Prawa Cywilnego)' in Państwo i Prawo, 3:117-136.

Banakas, S. (2015). 'Non-Pecuniary Loss in Personal Injury: Topography Architecture and Nomenclature in the European Landscape' in Journal of Comparative Law 10:291342.

Bargelli, E. (2005). 'Italy' in Koziol, H. \& Steininger, B. C. (Eds.), European Tort Law. Vienna: Springer, 368-379.

Brüggemeier, G. (2010). 'Protection of personality rights in the law of delict/torts in Europe: mapping out paradigms' in Brüggemeier, G., Colombi Ciacchi, A. \& O'Callaghan, P. (Eds.) Personality Rights in European Tort Law. Cambridge: Cambridge University Press. 5-10.

Grzeszak, T. (2018). Dobro osobiste jako dobro zindywidualizowane in Przeglad Sadowy 4:7-41.

Grzeszak, T. (2019). 'Zdrada małżeńska a naruszenie dóbr osobistych w orzecznictwie Sądu Najwyższego' in Monitor Prawniczy 11:607-610.

Kryla-Cudna, K. (2018). Zadośćuczynienie pieniężne za szkodę niemajątkowa powstała wskutek niewykonania lub nienależytego wykonania umowy. Warszawa: C.H. Beck.

Kubiak-Cyrul, A. (2013). 'Personality Rights in Poland' in Opolskie Studia AdministracyjnoPrawne 3:71-94.

Neethling, J. (2005). 'Personality rights: a comparative overview' in The Comparative and International Law Journal of Southern Africa 38(2):210-245.

Rogers, W.V.H. (2005). Principles of European tort law: text and commentary. Wien, New York: Springer-Verlag.

Lahe, J. \& I. Kull (2016). 'Compensation of non-pecuniary damage to persons close to the deceased or to the aggrieved person' in International Comparative Jurisprudence 2(1) $1-7$.

Steininger, B.C. (2005). 'Austria' in Koziol, H. \& Steininger, B.C. (Eds.), European Tort Law. Vienna: Springer 118-155.

Steininger, B.C. (2018). 'The Protection of Personality Rights in Comparative Perspective: Basic Questions' in K. Oliphant, Zh. Pinghua \& Ch. Lei (Eds.), The Legal Protection of Personality Rights: Chinese and European Perspectives. Leiden: Brill/Nijhoff 1323.

Strugała, R. (2019). Dobra i interesy chronione w strukturze czynu niedozwolonego. Warszawa: C.H. Beck.

Traple, E. (2020). 'Nadużycie instytucji ochrony dóbr osobistych w praktyce orzeczniczej sądów polskich' in Pisuliński, J. \& Zawadzka, J. (Eds.), Aksjologia prawa cywilnego i cywilnoprawna ochrona dóbr. Warszawa: C.H. Beck 139-161.

van Dam, C. (2013). European Tort Law, $2^{\text {nd }}$ ed. Oxford: Oxford University Press.

\section{Cases}

Case C-168/00, Simone Leitner v. TUI Deutschland GmbH \& Co. KG, Judgment of 12 March 2002 (Sixth Chamber), ECR 2002, I-2631

Judgement of the Regional Court in Koszalin dated 22 February 2011 (I C 124/10)

Judgement of the Regional Court in Olsztyn dated 24 February 2015 (I C 726/13)

Judgement of the Regional Court in Cracow dated 7 September 2017 (II Ca 1111/17) 
Judgement of the Appellate Court in Warsaw dated 31 March 2016 (I ACa 971/15) Judgement of the Appellate Court in Cracow dated 22 December 2016 (I ACa 1080/16) Judgement of the Court of Appeal in Białystok dated 13 January 2021 (I ACa 289/20) Resolution of the Polish Supreme Court dated 27 March 2018 (III CZP 36/17) Judgement of the Polish Supreme Court dated 11 December 2018 (IV CNP 31/17) Resolution of the Polish Supreme Court dated 22 October 2019 (I NSNZP 2/19) 
